\title{
A tribute to Ložek (1965): The problem of loess formation and the loess molluscs
}

\author{
Denis-Didier Rousseau ${ }^{1,2}$ \\ ${ }^{1}$ Geosciences Montpellier, University of Montpellier, CNRS, Montpellier, France \\ ${ }^{2}$ Lamont-Doherty Earth Observatory, Columbia University, New York, NY 10964, USA
}

Correspondence: Denis-Didier Rousseau (denis-didier.rousseau@umontpellier.fr)

Relevant dates: $\quad$ Received: 11 August 2021 - Revised: 6 September 2021 - Accepted: 5 November 2021 Published: 17 December 2021

How to cite: $\quad$ Rousseau, D.-D.: A tribute to Ložek (1965): The problem of loess formation and the loess molluscs, E\&G Quaternary Sci. J., 70, 229-233, https://doi.org/10.5194/egqsj-70-229-2021, 2021.

Special issue statement. This article is part of a special issue published on the occasion of the 70th anniversary of $E \& G$ Quaternary Science Journal (EGQSJ). The special issue celebrates the journal's notable contribution to Quaternary research by revisiting selected milestone articles published in the long history of EGQSJ. The German Quaternary Association (DEUQUA) presents translations of the originals and critical appraisals of their impact in tandem anniversary issues of DEUQUASP and EGQSJ, respectively.

Original article: https://doi.org/10.3285/eg.16.1.05

Translation: https://doi.org/10.5194/deuquasp-367-2021

When addressing the nature and origin of loess deposits and the associated environment as deduced from terrestrial mollusc faunas, Vojen Ložek produced a synthetic review of the state of the art at that time (Ložek, 1965a). This synthesis was one among several papers that he published the same year in English about "The loess environment in Central Europe" (Ložek, 1965c) or "Problems of analysis of the Quaternary nonmarine molluscan fauna in Europe" (Ložek, 1965b). It was mainly based on his own experience of investigating terrestrial molluscs in Czechoslovakian Quaternary deposits.

In his seminal paper, Ložek addresses key issues, which remain valid and are still relevant nowadays -56 years later! Ložek noticed the problem "that it is surprising how little attention has been paid to the mollusc fauna, which occurs so frequently in loess that it can rightly be considered one of the main characteristics of this sediment". Such a key statement still prevails today by comparison with other proxies which appear much more popular. This leads Ložek to conclude that "we still see that this goes far beyond the framework of the loess problem".

Ložek initially addresses the critical question of loess formation, indicating that at that time there were two schools: soil scientists and bio-geoscientists. Interestingly, such distinction remains until the present; however, the differentiation between the two today seems to rather correspond to a problem of the scale at which the relevant processes and mechanisms are analysed. Ložek gives preference to the aeolian hypothesis of loess formation, what he termed "Richthofenian hypothesis", by reference to Ferdinand von Richthofen, who first proposed that loess was aeolian in origin. He adds the critical assumption that "it is clear that the loess is to be regarded as the product of a peculiar environment which has no parallel in present-day Europe".

With Ložek's correct and concrete statement that "molluscs are best suited, as they are more abundant than the vertebrates in the loess and the related deposits", it is easier to understand the sampling protocol developed by Ložek and his followers. About $10 \mathrm{~kg}$ of sediment needs to be sampled and sieved in order to retrieve the remaining shells. During this procedure, bones or even skulls of micromammals and 
rodent teeth are frequently found among the numerous shells, making vertebrates a sub-product of mollusc studies!

Ložek states "molluscs are so widespread and common in loess that the presence of shells has to be seen as one of the main characteristics of loess". This statement may be biased by his own experience of central European mollusc assemblages, where this finding holds true. However, not noticing shells from an outcrop does not imply the absence of any shells in a loess sample, as they have a great variability in size. Ložek further states that the "largest number of finds is indisputably known from the loess areas of Germany and Czechoslovakia". This statement is clearly not precise enough. Is he considering the number of shells, i.e. abundance? Or is he considering the number of species, i.e. richness? There are other more precise ecological indices allowing for a description of mollusc communities, like diversity and equitability, which refers to the ecosystems they live in. Therefore, the conclusion reached can be totally different. Ložek's vague statement may, however, simply be reflecting the state of the art of terrestrial mollusc studies at that time. Expanding the geographical range of his statement, he acknowledges the lack of useful information from Asia and indicates a kind of parallelism of North American loess mollusc faunas with the ones from Europe, with "many developmental traits ... specific to America". Although loess mollusc faunas have been identified in Chinese loess series, loess mollusc faunas in North America indeed show similar characteristics to those of Europe but with properties inherited from biological evolution: different species of the same genus but showing almost identical ecological requirements. Similarly, Ložek refers to the fading of the loess faunas towards the south, concluding that loess had been deposited with its associated mollusc faunas living in the sediment, although under different climate conditions. This leads Ložek to conclude that there must have been different climate zones in the Quaternary.

To explain the lack of efficient comparison with other regions, Ložek lists four reasons, which are still relevant and valid today. He emphasises the very need for careful observation of the shells and determination of the species. The identification at the species level is not always easy, and some variability exists in the shape and ornamentation of the shell of a single species. Careless and surficial investigations of the shells can significantly change the interpretation of a mollusc assemblage, which Ložek pointed out. This resulted in the identification of mollusc assemblages, named after key species, basically the Pupilla and the Columella faunas, with variations in their composition resulting from environmental conditions and geographical locations. Ložek summarised this interpretation, which is commented on in Table 1.

Making a turn to Asian loess, Ložek states that it "could perhaps be argued that loess in Asia formed under different conditions ... and that the term mentioned should refer primarily to this environment". Over the last few decades it has been demonstrated that one ought to remove the "perhaps"; i.e. Asian loess did indeed form under different conditions with different sources than those of European loess.

Defining subzones among the loess landscapes, Ložek indicates that loess deposits mainly occurred in dry and lowelevation areas. Indeed, recent studies (e.g. Rousseau et al., 2014) have demonstrated that at least in Europe loess was deposited at lower elevations in relation to the dust transport dynamics and that the source of the transported material is mostly regional or local. Therefore, Ložek correctly speaks of fairly uniform faunas from a fairly uniform environment. However, he reconciles with the soil hypothesis by stating that the "fauna of the loess phases thus clearly testifies to peculiar soil conditions, and confirms that the loess is to be regarded not only as a product of wind sedimentation but also of a specific soil-forming process".

Ložek further tries to summarise the complexity of the loessification process, still referring to the presence of molluscs as a key indicator: "The mollusc analyses showed that the soil and environmental conditions were really quite peculiar and that the assumption of a special loessification process seems completely justified". Such a statement could be given nowadays without relying on the mollusc analyses, especially from sequences or deposits where there are no snails reported. However, the peculiarity of the mollusc assemblages was key to characterising the loess environments. From that, Ložek drew four general conclusions that are still valid even if the third one needs to be discussed a little more.

1. Ložek states, "thanks to the loessification process ... The $\mathrm{CaCO}_{3}$ precipitation and the specific iron compounds, which determines the colour of the loessification products, are characteristics features". The pale yellow colour of the unstratified loess units and the presence of carbonate concretions, the loess dolls, are indeed characteristic features allowing the clear identification of loess layers as described initially by von Leonard (Smalley et al., 2001).

2. Ložek states, "the formation of loess is not only due to the accumulation of dust". This is a correct statement! This assumption, however, was only expressed years later by Pecsi in his paper "Loess is not just the accumulation of dust" (Pecsi, 1990).

3. Ložek states, "the particular chemistry of loess deposits and weathering products allow the appearance and proliferation of some steppe molluscs and apparently also characteristic vegetation". I would rather reverse the arguments: the particular vegetation allows the appearance and proliferation of mollusc populations. Mollusc individuals and species grow and develop because environmental conditions allow them to do so: with vegetation not only to feed on but also to use to hide from temperature and precipitation variations. Moreover, the occurrence of carbonate in the dust or the soil would also favour the development of mollusc populations. 
Table 1. Comments on Ložek's original statements about the loess mollusc faunas.

\begin{tabular}{lll}
\hline Original statement & Validity & Comment \\
\hline $\begin{array}{l}\text { (1) "The loess faunas represent closed autochthonous } \\
\text { populations, which have no analogy in the present". }\end{array}$ & Partly yes & $\begin{array}{l}\text { The Pupilla fauna fits with this statement, espe- } \\
\text { cially because of the particular association of the } \\
\text { various Pupilla species, while the Columella fauna } \\
\text { does not, as similar communities can partly be } \\
\text { found presently in Europe. }\end{array}$
\end{tabular}

(2) "They consist of a relatively small number of cold- Yes hardy species, which indicate open, largely wood-free formations (and can live today in cold steppes, tundra as well as in the high mountains)".

(3) "The mollusc fauna is characterised by a few special species that occur almost exclusively in loess; species common elsewhere are also represented by special races and forms and often have different ecological requirements compared to the present".

\section{Yes}

This statement refers to a longitudinal and latitudinal knowledge and interpretation of the modern distribution of the species at that time that has evolved since then and that I used later in proposing reconstructing quantitative estimates of past temperatures and precipitation.

In fact, using biometry, I have demonstrated the occurrence of ecophenotypism not only in modern populations of Pupilla muscorum but also in fossil ones, especially in loess series with higher shells present in glacial deposits or more continental conditions, while shorter ones prevailed in interglacial units or in western environments (Rousseau, 1997). Similar variations have also been noticed with other eurytherm species like Trochulus hispidus (formerly Trichia hispida) or Succinea oblonga, present also in loess mollusc fauna through the $S$. oblonga elongate form in layers corresponding to the coldest conditions.
(4) "On the basis of detailed analyses of loess faunas, a whole series of mollusc communities have been dis-

Roughly speaking yes tinguished, some of which are bound to certain areas, others to certain biotopes (e.g. through different relief conditions)".

This is correct, and one can follow the time evolution of the ecosystems in time from interglacial to glacial ones (Rousseau, 1987). Among the latter, "the loess fauna forms a closed monotonous unit that is clearly distinguishable from all other Quaternary mollusc communities". Rather than monotonous, I would rather qualify the loess fauna as particular as one could immediately refer to particular environmental conditions.

(5) "A loess fauna with the described characteristics Yes is distributed in a huge area, in which currently very diverse mollusc communities live, which indicates a far-reaching leveling of the environmental conditions, which has no analogy in other sections of the Quaternary".
Loess deposits are capping worldwide areas, especially in the Northern Hemisphere corresponding to glacial open landscapes with very little vegetation. Such general environmental characteristics induce biomes that are relatively homogenous with slight local or regional adaptations, what Ložek calls "loess biotopes or loess environment". This is far different from environmental conditions mostly corresponding to interglacial conditions during which the local and regional specificities took over and which are expressed by more specialised and diverse biomes (here the association of vegetation and fauna).
However, it is possible to observe modern terrestrial snails living in a more acidic environment, but under such conditions, they often show very thin and fragile shells that will not be preserved after the death of the animal. Moreover, later Ložek states "the loess environ- ment is especially favourable for snails but the species richness is quite limited due to harsh climate and aridity". A loess environment is favourable for snails if there is enough carbonate available to build their shells. In addition, the notion of harsh climate appears rather vague. 
Apparently, Ložek refers to temperature, but as this is a limiting factor in general, some species can endure various temperature minimums, allowing them to be observed at very high latitudes or elevation. As a complement to these points, one should refer to the main limiting factors that constrain the growth of terrestrial molluscs found in the loess deposits: the impacts of both temperature and hibernation. Other factors like precipitation, moisture, and dust can also impact the growth of the terrestrial molluscs. Knowing these limitations allows us to understand the low number of species able to face the drastic environmental and climatic conditions under which the loess was deposited. In fact, loess faunas are composed theoretically of mollusc species, which are either eurytherm (large temperature range tolerance) or stenothermic (limited and specific temperature range tolerance). However, precipitation has been a second important limiting factor. This has been demonstrated by comparing loess faunas over Europe, showing a strong reduction in the richness westwards. Therefore, one ought to speak in terms of seasonality, especially of the interval from spring to autumn when the molluscs have some metabolic activity.

4. Ložek states, "the formation of loess and loess-like formations is thus closely linked to specific climatic and vegetation conditions". This ought to be more precise. In fact, only during cold and glacial conditions are deflation areas created, which is a prerequisite for the production of aeolian material. In general, those areas are outwashes of glaciers or ice sheets, moraines, and riverbeds. The vegetation is important not only in the deposition area to trap the aeolian dust but also in the deflation area, in the emission process. Modelling studies (Sima et al., 2013) have demonstrated that if the vegetation is too high, later in spring, the aeolian material cannot be emitted and therefore transported. Conversely, if the vegetation has not grown enough but the ground is still frozen, the aeolian material cannot, irrespective of wind speed, be emitted.

In addition, Ložek discusses the hypothesis of interglacial loess, known today as typically a glacial sediment. He also states, "It is equally misleading to compare the present conditions in the alpine region of Central Europe mountains with the conditions of other areas during the loess phases". This is only true with regard to the average annual temperature but does not apply to the humidity, which is very high in the mountains, while the loess climate must have been arid. Although such a statement may be appropriate concerning temperature, the degree of aridity must be questioned. Indeed, there must have been some seasonality allowing the vegetation to grow in spring and thus to trap the aeolian material (Sima et al., 2013).

Ložek discusses further what is called the loess interlayers, mostly found in pedocomplexes, which themselves are related to odd marine isotope stages (Kukla, 1977), and highlights the importance of the precise observation of the outcrop stratigraphy. This could be considered a misleading interpretation of the interglacial loess hypothesis. Indeed, some of these particular units have been named "markers" by Kukla (1977) and correspond to specific climate conditions. The best example is given from the Dolní Věstonice record of the last climate cycle, where several of these units have been described (Kukla and Ložek, 1961; Rousseau et al., 2013). In fact, when Ložek's paper was published, interglacials were still interpreted as a single temperate episode, while later investigations demonstrated a much more complex history marked by the occurrence of stadials.

Ložek further points out the importance of aeolian activity "not being underestimated". We know now that this activity is very basic as aeolian material is the source of the deposited material. This is indeed best evidenced when among the transported material elements, fossils or particular grains or granules, where characteristics of the source region can be found, supporting therefore the regional origin of the transported material.

Ložek also noted the bedding of some loess units. They are mostly related to slope deposits but may also be related to dust deposits on snow, resulting in such facies after the snow had melted. He states that, "at the time of loess accumulation at the foot of a slope, slope transport and the formation of coarser debris were limited to the lowest degree". This appears logical because of not only the drier conditions of the dust deposition but also the substratum being frozen during most of the year, preventing major sediment movement. On the contrary, the soil complexes show units corresponding to slope deposits that were described by Kukla (1977) as pellet sands representing the erosion by heavy rains of sedimentary units deposited or developed on the slope itself. Other forms of laminations occur in western and eastern loess sequences, named "limon à doublets", which are mostly postsedimentary in origin.

Intense calcareous precipitation at the end of the cold periods is another misleading assumption by Ložek. In fact, the carbonate precipitation marks the lower limit of soil formation and development. The pedogenesis actually started at the top of the aeolian unit, after the dust accumulation had stopped, and produced large carbonate concretions at the base of the paleosols by leaching of the loess sediment. Therefore, precipitation of carbonates occurred during the interglacials and not at the end of cold periods.

With respect to loess deposition Ložek claims that "the entire environmental conditions at that time were very peculiar and ... they have no equivalent in present day Europe". He goes further by stating that loess characterises the late phases of highly glacial periods in the Pleistocene of Europe. We should amend this statement by saying that in general, loess is noticed and observed in deposits corresponding to glacial (odd marine isotope stages) or stadial conditions. 
Some final reservations should be raised regarding one major point of Ložek's work: he claims that the mollusc fauna "differs sharply from all other cold and warm period communities, which is undoubtedly due to the condition of the substrate". According to present analyses and from the ecological requirement of the modern representatives of the identified species, this is not certain.

In conclusion, the present paper appeared 1 year after the release of Ložek's doctoral thesis "Quartärmollusken der Tschechoslowakei" (Ložek, 1964), in which he had developed many more points compared to what he addresses here. In his paper he chose to make his vision and the ones Czechoslovakian loess researchers had at that time visible to the international community. Ložek presented a detailed and complete state-of-the-art loess and mollusc study. This paper represents therefore an extraordinarily synthetic review, which still has a modern flavour as many of the aspects addressed remain relevant today. I am proud to have met Vojen Ložek in person several times and to have conducted fieldwork with him around Prague and in Moravia.

Acknowledgements. I would like to thank Frank Preusser, Markus Fuchs, and Christine Thiel for inviting me to participate in this very special tribute series and the anonymous reviewer for comments on the original draft. This is a LDEO contribution.

Financial support. The article processing charge was funded by the Quaternary scientific community, as represented by the host institution of EGQSJ, the German Quaternary Association (DEUQUA).

Review statement. This paper was edited by Christine Thiel and reviewed by one anonymous referee.

\section{References}

Kukla, G.: Pleistocene land-sea correlations. 1. Europe, Earth-Sci. Rev., 13, 307-374, 1977.

Kukla, G. and Ložek, V.: Loess and related deposits, in: Survey of Czechoslovak Quaternary, Czwartozed Europy Srodkowej i Wschodniej, INQUA 6th Int. Congr., Inst Geol Pr. Warszawa, 34, 11-28, 1961.
Ložek, V.: Quartärmollusken der Tschechoslowakei, Rozpr. Ustred. ustavu. Geol., Verlag der Tschechoslowakischen Akademie der Wissenschaften, Praha, 374 pp., 1964.

Ložek, V.: Das Problem der Lößbildung und die Lößmollusken, E\&G Quaternary Sci. J., 16, 61-75, https://doi.org/10.3285/eg.16.1.05, 1965a.

Ložek, V.: Problems of analysis of the Quaternary nonmarine molluscan fauna in Europe, Geol. Soc. Am. Spec. Pap., 84, 201-218, 1965b.

Ložek, V.: The loess environment in Central Europe, in: Loess and related eolian deposits of the world, Linc. Univ. Press, 67-80, 1965c.

Pecsi, M.: Loess is not just the accumulation of dust, Quatern. Int., 7/8, 1-21, 1990 .

Rousseau, D. D.: Paleoclimatology of the Achenheim Series (Middle and Upper Pleistocene, Alsace, France) - a Malacological Analysis, Palaeogeogr. Palaeoclim, 59, 293-314, 1987.

Rousseau, D. D.: The weight of internal and external constraints on Pupilla muscorum L. (Gastropoda: Stylommatophora) during the Quaternary in Europe, in: Past and Future Rapid Environmental Changes: The Spatial and Evolutionary Responses of Terrestrial Biota, edited by: Huntley B, Cramer, W., Morgan, A. V., Prentice, H. C., and Allen, J. R. M., Springer-Verlag, Heidelberg, 47, $303-$ 318, 1997.

Rousseau, D.-D., Ghil, M., Kukla, G., Sima, A., Antoine, P., Fuchs, M., Hatté, C., Lagroix, F., Debret, M., and Moine, O.: Major dust events in Europe during marine isotope stage 5 (130-74 ka): a climatic interpretation of the "markers", Clim. Past, 9, 2213-2230, https://doi.org/10.5194/cp-9-2213-2013, 2013.

Rousseau, D.-D., Chauvel, C., Sima, A., Hatte, C., Lagroix, F., Antoine, P., Balkanski, Y., Fuchs, M., Mellett, C., Kageyama, M., Ramstein, G., and Lang, A.: European glacial dust deposits: Geochemical constraints on atmospheric dust cycle modeling, Geophys. Res. Lett., 41, 7666-7674, https://doi.org/10.1002/2014gl061382, 2014.

Sima, A., Kageyama, M., Rousseau, D.-D., Ramstein, G., Balkanski, Y., Antoine, P., and Hatté, C.: Modeling dust emission response to North Atlantic millennial-scale climate variations from the perspective of East European MIS 3 loess deposits, Clim. Past, 9, 1385-1402, https://doi.org/10.5194/cp-9-13852013, 2013.

Smalley, I. J., Jefferson, I. F., Dijkstra, T. A., and Derbyshire, E.: Some major events in the development of the scientific study of loess, Earth-Sci. Rev., 54, 5-18, 2001. 